\title{
Powiedz tylko, że jestem... Jana Dormana Eksperymentalny Teatr Dziecka
}

Otrzymałem zaproszenie na otwarcie „Teatru Dziecka”.

[...] Zastanowiła mnie nazwa, „Teatr Dziecka”, a więc nie tylko teatr dla dziecka. Mała, lecz zasadnicza różnica. [...] Po oglądnięciu widowiska przekonałem się, że praca ta oparta jest na rzetelnym studium psychiki dziecka, nie hamuje instynktownych i wartościowych odruchów dziecka przejawiających się $w$ formach niedocenionych i niezrozumiałych niejednokrotnie przez człowieka dorosłego, lecz przeciwnie, pobudza je i rozwija. Teatr dziecka jest wielką zabawą dzieci dla dzieci. Przekonał mnie o tym sposób przeprowadzenia widowiska1.

Tak oto, ponad pięćdziesiąt lat temu, o teatrze Jana Dormana wypowiadał się na łamach „Dziennika Zachodniego” Stanisław Marcinow. Mimo upływu lat J. Dorman i jego koncepcja teatru dziecięcego nadal wzbudzają kontrowersje. Dzieje się tak, ponieważ artysta zerwał z ogólnie przyjętymi zasadami tworzenia przedstawień dla dzieci i z dziećmi jako aktorami. Dorman konsekwentnie trzymał się swoich założeń, które oparte były na własnych doświadczeniach teatralnych wyniesionych z dzieciństwa, przeżyciach związanych z tworzeniem spektakli w teatrze szkolnym Męskiego Seminarium Nauczycielskiego, wreszcie na obserwacjach pedagogicznych, prowadzonych na Podlasiu i w Krakowie, gdzie studiował na Akademii Sztuk Pięknych. Bogate i pracowite artystycznie życie J. Dormana zaowocowało licznymi inscenizacjami, które przeszły do historii teatru dziecięcego, jego zaangażowanie i wysiłek twórczy często doceniane były dopiero po latach. Sam Dorman nieustannie rozwijał i doskonalił swoje pomysły,

* Dr hab., prof. UŁ, Katedra Pedagogiki Przedszkolnej i Wczesnoszkolnej, Wydział Nauk o Wychowaniu, Uniwersytet Łódzki, 91-408 Łódź, ul. Pomorska 46/48.

1 S. M a r c in o w, Wielka zabawa, „Dziennik Zachodni” 1947, nr 182 (855), s. 12. 
wizje i zamierzenia. We własnym teatrze był reżyserem, scenografem, aktorem, organizował szkolenia dla nauczycieli, przeglądy teatralne, działał na rzecz społeczności lokalnej. Był człowiekiem o rozległych zainteresowaniach, zawsze gotowym do dalszego rozwoju i kształcenia, otwartym na świat i ludzi, zwłaszcza na potrzeby dzieci. Kilka lat po śmierci artysty Pracownia Dokumentacji Teatru Lalek przy teatrze Arlekin w Łodzi, wydająca zeszyty pt. „Lalkarze”, dziesiąty numer serii poświęciła dokonaniom artystycznym J. Dormana. Podsumowując osiągnięcia twórcy, Lucyna Kozień pisała:

Jan Dorman tworzył teatr autorski, pisał bądź adaptował teksty, reżyserował, tworzył oprawę plastyczną i opracowania muzyczne, projektował programy teatralne i pisał do nich teksty, osobiście wprowadzał widzów do teatru, a czasami nawet grał w swoich spektaklach zastępując nieobecnych aktorów. Był niezmiernie aktywny i pełen pasji działania. Organizował spotkania, przeglądy teatralne, dyskusje, seminaria i odczyty z udziałem znaczących naukowców i krytyków sztuki, chętnie uczestniczył w kursach i warsztatach teatralnych, szkolił aktorów i adeptów sztuki, był znanym społecznikiem Będzina, działał w SPATIFie i ministerialnych komisjach, współpracował z teatralnym ruchem amatorskim, pisał do gazet (lubił pisać recenzje teatralne), wygłaszał referaty, urządzał wystawy plastyczne, wykładał w szkole teatralnej, zbierał pieśni i wyliczanki, i zajmował się tysiącem innych spraw ważnych dla teatru, dla miasta i dla niego samego ${ }^{2}$.

Tak liczne dziedziny zainteresowania i działalności sprawiają, że kompleksowa ocena jego dokonań jest niezwykle trudna, niewątpliwie jednak J. Dorman zasługuje na trwałe miejsce w panteonie osób mających znaczący wpływ na metody pracy twórczej z dziećmi. Przy rozważaniach o eksperymentalnym teatrze dziecięcym trzeba wyraźnie zaznaczyć, że Dorman był założycielem dwóch scen: teatru dziecięcego - tzw. teatru zabawy i zawodowego teatru dla dzieci. Obydwie te sceny prowadził według własnych koncepcji i spójnych założeń, w których szeroko pojęty rozwój intelektualny i emocjonalny dziecka był priorytetem. Każdy ze wspomnianych teatrów miał w sobie pierwiastek nowości i niekonwencjonalności, scena ekspresji to zabawa dzieci w teatr, scena impresji to profesjonalny teatr aktorski dla dzieci. Na deskach obydwu scen dochodziło do niespotykanych wcześniej w teatrze doświadczeń, eksperymentów na dziecięcej wyobraźni, wrażliwości i empatii. Zawodowy teatr aktorski wsławił się „trudnym” repertuarem, poważnym traktowaniem swojego widza, oryginalną oprawą wizualną spektakli, ciekawą muzyką, nowymi technikami kreowania wydarzeń na scenie. Teatr amatorski, dziecięca scena ekspresji - to autentyczna, nieskrępowana twórczość dziecka, wywodząca się z zabawy, z ledwie nakreślonym scenariuszem, w dużej mierze oparta na improwizacji.

Choć na przestrzeni lat patronat nad działalnością artystyczną Dormana przejmowały różne instytucje, zmieniając nazwy teatru, miejsca jego usytuowania i metody pracy, to jednak założenia twórcy pozostały niezmienne - teatr miał rozwijać, prowokować do myślenia, pobudzać wyobraźnię. Burzliwe losy Dormanowskiej idei teatru dla dzieci powiązane były z Międzyszkolnym Teatrem Dziecka przy Inspektoracie Szkolnym w Sosnowcu (1945), Eksperymentalnym Teatrem

2 Zob. L. Ko z i e ń, Jan Dorman, „Lalkarze” 1996, z. 10, s. 54. 
Dziecka Centralnego Związku Zawodowego Górników w Sosnowcu (1946), Eksperymentalnym Teatrem Dziecka Centralnego Związku Zawodowego Pracowników Przemysłu Chemicznego w Będzinie (1949), by od roku 1950 połączyć się na trzydzieści lat z będzińskim Teatrem Dzieci Zagłębia.

W roku 1959 Teatr Dzieci Zagłębia został „upaństwowiony” i przypisany do teatru lalkowego, co spowodowało zmiany konwencji i działań tejże sceny. Artystyczne wizje Dormana musiały się „zmieścić” w koncepcyjnych ramach teatru lalki, w efekcie czego „po drodze zaginęła niestety dziecięca scena ekspresji. Doświadczenia te jednak pozostały w praktyce teatralnej Dormana: dziecko było tu zawsze poważnie traktowanym partnerem; jego zabawa - inspiracją artystyczną"3.

Mimo modyfikacji narzuconych „odgórnie”, zgodnych z wymogami „planów usługowych”, którym zaczął podlegać Teatr Dzieci Zagłębia, Dorman nie podporządkowywał się panującym stylom, tworząc niekonwencjonalne przedstawienia, „przemycał” dziecięcą zabawę na deski swojej sceny. Mówiąc o eksperymentalnym teatrze dziecięcym J. Dormana myślimy - jak już wspomniałam - nie tylko o scenie ekspresji, lecz także o scenie impresji, gdyż obydwa nurty wyróżniały się awangardową formą i poddawały dziecięce umysły niespotykanej stymulacji.

Dormanowska koncepcja teatralna sprowadzała się do kilku innowacyjnych założeń, które w znaczący sposób wpływały na całokształt procesu przygotowań, realizacji i samego wystawienia spektaklu. Dla dobrego zrozumienia zamysłu artystycznego Dormana należy przywołać jego słynne motto: „Dziecko - to nie jest mały człowieczek. To jest INNY CZŁOWIEK"4. Tej myśli podporządkował Dorman repertuar, wybór scenografii, muzyki, sposób reżyserii, słowem wszystkie działania twórcze. Dziecko znajdowało się w centrum uwagi, nie było postrzegane jako nieukształtowana istota ludzka, ale jako odrębna jednostka, wymagająca specyficznego języka, jednak przekazywane jej treści miały być wartościowe i przydatne. Pedagog Dorman widział w dziecku pełnoprawnego partnera, któremu należy się szacunek i zrozumienie, w tym duchu pracował i tworzył swe spektakle. Jego najmłodsza córka Iwona Dowsilas, założycielka Fundacji im. Jana Dormana, wspomina: „Ojciec zawsze był przekorny, tworzył teatr, w którym nie było miejsca na infantylizm"5. Ten niezwykle wyraźny przejaw poważnego traktowania swoich aktorów i widowni podkreślał sam zainteresowany przy każdej nadarzającej się okazji. Świadczyć o tym mogą przytaczane przez jego wieloletniego przyjaciela, Andrzeja Linerta, słowa samego twórcy: „Dziecko to taki sam człowiek jak dorosły, tylko że mniejszy. Nie można zatem traktować go infantylnie"6.

Postrzeganie dziecka jako indywidualnej jednostki, która nie ma ograniczeń, a tylko specyficzny sposób rozumienia świata, przekładało się na wybór repertuaru Teatru Dzieci Zagłębia, który wielokrotnie krytykowali przeciwnicy Dormana. Na scenę impresji wybierał teksty trudne, nieprzystające do kanonu dziecięcego repertuaru, odrzucane były miałkie opowiastki na rzecz historii pobudzających

3 T. O gro d z iń s k a, Dormana teatr dla dzieci, „Dialog” 1987, nr 2, s. 150.

4 F. N e tz, Teatr Dormana, „Panorama” 1979, nr 3, s. 8.

5 I. D o w s il a s, Niezwykły teatr Dormana, „Trybuna” 2000, nr 24, s. 3.

6 A. Line rt, Dziedzictwo Dormana, „Śląsk” 1997, nr 3, s. 70. 
wyobraźnię, zmuszających do refleksji i budowania własnej wizji świata. Twórca postrzegał życie jako swoistą całość, uważał że każdy okres istnienia ludzkiego jest ważny - dlatego nie należy dzieciństwa traktować jako nieistotnego epizodu i podawać w tym czasie dzieciom schematycznych i banalnych treści. Dorman, poszerzając krąg swojego oddziaływania i poszukując coraz to nowych odbiorców, dzieciństwo pojmował jako fragment integralnej całości życia człowieka. Stąd te same prawa i ten sam stosunek do efektów własnej pracy obowiązywały u niego niezależnie od tego, czy tworzył z myślą o dziecku, czy też o dorosłych. Dzięki takiemu spojrzeniu na okres dzieciństwa, sztuki wystawiane na scenie Teatru Dzieci Zagłębia poruszały tematy ważne, uniwersalne i ponadczasowe. Wiara w możliwości percepcyjne małoletnich widzów była u Dormana niezwykle silna i pewna, mimo że i ten aspekt pracy artysty spotykał się niejednokrotnie z nieprzychylnymi komentarzami. Nowością na scenie dziecięcej było wystawianie przedstawień przygotowywanych na motywach twórczości klasyków literatury dla dorosłych. Dorman uważał, że: „Jego Teatr jest winien małym widzom wielką literaturę i rzeczywiście wystawiał repertuar, o jakim nie mógł marzyć żaden teatr dla dzieci - np. dzieła Maeterlincka, Szekspira, Tołstoja, Wilde’a, Błoka, Majakowskiego, Woltera, Witkacego, Goethego"8.

Koncepcja Dormana zakładała, że młody człowiek jest gotowy na odbiór nawet trudnych widowisk, ponieważ dziecięce rozumienie odbywa się na innej płaszczyźnie, w sferze wrażliwości, duchowości i estetycznych doznań. Trywializowanie treści przekazywanych dzieciom nie służy ich rozwojowi, gdyż blokuje możliwości poznawcze, a przecież dzieci potrzebują bodźców do rozkwitu, do poszukiwania swojej drogi, do właściwego rozumienia emocji. Dorman, tworząc swoje spektakle, opierał się głównie na tekstach znanych, uznanych, ale je przerabiał. Twierdził, że taki sposób zbliża go do kształtu scenariusza, o który mu chodzi. Jak podkreśla Tadeusz Byrski:

Dorman ma w portfelu i Makuszyńskiego, i Kownacką, i Saint-Exupery’go, i Błoka, i Diderota. Czerpie pełną ręką z literatury. Chyba słusznie, nie może dziecko ciągle być karmione przeżutą papką lukrującą świat i życie; zamykającą wszystkie troski do „bubu pluszowy niedźwiadek” i do czerwonego kapturka ${ }^{9}$.

Dorman widział swoją rolę bardzo konkretnie - po pierwsze był pedagogiem, dydaktykiem, po drugie reżyserem, twórcą, kreatorem wrażeń estetycznych. W wywiadzie udzielonym Marii Mikołajczyk dla „Gazety Zachodniej” wyjawił swój punkt widzenia na rolę teatru w kształtowaniu młodych umysłów:

Chcę kształtować dziecko, właśnie nie kształcić, lecz kształtować. Teatr może być ważnym elementem wpływającym na dziecięcą osobowość, może dopomagać we właściwej selekcji sumy wrażeń i informacji, które do dziecka docierają. Często nasze przedstawienia zawierają ładunek artystyczny, którego pełen odbiór nie jest dla dziecka możliwy. Np. aktor mówi tekst Błoka; dziecko nie może pojąć go w pełni, jednak uczy się przez takie zjawiska, czym jest poezja. Także w stosunku do odbiorcy

7 Tamże.

8 I. D ow sila s, Niezwykły teatr..., s. 3.

9 T. B y r s ki, Pieśń i praktyczność, „Więż” 1973, nr 2, s. 5. 
dziecięcego nie powinniśmy „iść na łatwiznę”. Nie powinniśmy się dostosowywać do stereotypowych upodobań wpajanych małemu widzowi, my musimy mieć ambicję kształtowania tych upodobań ${ }^{10}$.

Jako pedagog z dużym doświadczeniem Dorman znał dziecięcy sposób odbierania rzeczywistości, dlatego uważał, że warto rozwijać w dziecku chęć poznawania świata, ciekawość, oddziaływać na wyobraźnię, pobudzać wrażliwość estetyczną i wspierać artystyczną aktywność.

W koncepcji Jana Dormana działalność teatrów impresji i ekspresji miała na celu rozwijanie szeroko rozumianych wartości wychowawczych, była swoistą lekcją estetyki, otwierała dzieciom drogę do pełniejszego rozumienia i przeżywania literatury, sztuki oraz wszelkiej działalności artystycznej.

Kolejnym niezwykle istotnym elementem koncepcji Dormana było założenie, że tekst spektaklu jest jedynie punktem jego wyjścia, scenariusz może być luźno oparty na podstawie literackiej, kurczowe trzymanie się pierwowzoru nie przyniesie efektów w postaci żywego, niosącego radość przedstawienia:

Dorman jest zwolennikiem integralności teatru jako sztuki. Wynika z tego służebna rola utworu scenicznego; staje się - w ręku reżysera jedynie tworzywem, z którego buduje on spektakl według własnych, częściowo tylko sugerowanych przez dramatopisarza koncepcji ${ }^{11}$.

Według Dormana, sztuka powinna się przeobrażać, żyć własnym rytmem, ewoluować, za każdym razem na nowo się odradzać. Jak podkreśla Teresa Ogrodzińska:

Znamienny jest stosunek Dormana do tekstu literackiego. Traktując słowo jako jeden z elementów teatralnego tworzywa, z tekstami dramatycznymi obchodzi się Dorman bezceremonialnie. Swobodnie kompiluje, skraca, dodaje tekst własny i wyliczanki, miesza stylistyki i konwencje ${ }^{12}$.

Siłą przedstawień dla dzieci i z dziecięcymi aktorami ma być zabawa, przyjemność wynikająca bądź z aktywności na scenie, bądź z oglądania widowisk prezentowanych w sposób bliski dziecięcym wyobrażeniom o rozrywce. W teatrze ekspresji to dzieci wyznaczały kształt i sposób realizacji spektaklu, reżyser nie trzymał się sztywno nawet własnych założeń, pozwalając swoim przedstawieniom rozwijać się zgodnie z nastrojem chwili. Na scenie impresji taka postawa wobec tekstu scenicznego również nie przysparzała twórcy eksperymentalnego teatru sojuszników. Seweryn Pollak w roku 1971 na łamach „Dialogu” zwracał uwagę na toczącą się w środowisku teatralnym dyskusję na temat znaczenia pierwotnego tekstu literackiego i implikacji związanych z jego przeróbkami. Jak pisał:

Wielka, zasadnicza dyskusja o prawie reżysera do naruszania integralnej jedności tekstu literackiego, do niejako współtwórczej interwencji w dzieło, dyskusja o granicach interpretacji scenicznej dramatu trwa i trwać będzie niewątpliwie, istnieje bowiem zbyt zasadnicza sprzeczność pomiędzy dwoma ścierającymi się koncepcjami. Zwolennicy jednej z nich w imię poszanowania nienaruszalności intencji

10 M. Mikołajc z y k, Dzieci nauczyły mnie teatru, „Gazeta Zachodnia” 1978, nr 80, s. 5.

11 S. Polla k, Teatr wielkiej przygody, „Teatr” 1967, nr 22, s. 15.

12 T. Ogrodzińs k a, Dormana teatr..., s. 154. 
twórcy żądają bezwzględnego zachowania przez reżysera tekstu utworu scenicznego i działalność jego sprowadza się do interpretacji utworu; zwolennicy koncepcji drugiej pojęcie interpretacji traktują bardzo szeroko - aż do przyznania reżyserowi prawa nie tylko do cięć, ale do przeróbek, uzupełnień, wstawek, wszelkich instrukcji, które mają na celu nie tyle ukazanie dzieła dramaturga, ile stworzenie na jego bazie przez reżysera dzieła samoistnego, odrębnego ${ }^{13}$.

Dzisiaj nikogo nie gorszą daleko idące przeróbki pierwowzorów literackich na potrzeby teatru czy kina, reżyserzy, scenarzyści dowolnie eksponują albo eliminują wybrane wątki, w efekcie czego powstają obrazy lub widowiska mające niewiele wspólnego z oryginałem. Obecnie nikogo nie dziwią opisy spektakli zawierające sformułowania typu „swobodna wariacja artystyczna na podstawie...” czy „spektakl luźno inspirowany powieścią”, ale czterdzieści, pięćdziesiąt lat temu tego rodzaju eksperymenty z tekstem budziły kontrowersje i często nie znajdowały zrozumienia wśród krytyków. Reżyser Dorman miał jednak swoją wizję, którą konsekwentnie realizował, jakby na przekór obowiązującym zasadom i kanonom. Wbrew krytycznym ocenom, mimo swobodnego podejścia do „bazy wyjściowej”, jaką jest pierwotny tekst literacki lub sceniczny, Dorman potrafił wybrane fragmenty utworów połączyć w spójną całość, która miała sens, zachowywała wymowę i intencje autorów. Istotnym elementem przedstawienia był dla niego rytm, to on wskazywał wybór poszczególnych scen, które reżyser łączył w jednolity utwór sceniczny. Przy opisie swojej metody Dorman najchętniej posługiwał się pojęciami z zakresu sztuk plastycznych i muzycznych. Szczegółowe zapisy przedstawień nazywał partyturami, odrzucając określenie „scenariusz”. Każda partytura obejmuje zapis działań aktora z przedmiotem, zapis intencji, wreszcie zapis ruchu aktorów ${ }^{14}$. Eksperymentalny teatr Dormana w kontekście ówczesnych zagorzałych sporów o wagę i „czystość” scenariusza jawił się jako oaza innowacyjności i nowatorstwa. Jak każdy człowiek postępu, Dorman spotykał się z brakiem zrozumienia, a czasami wręcz z odrzuceniem.

Znajomość psychologii dziecka poparta dobrym warsztatem pedagogicznym zaowocowała specyficznym podejściem twórcy do pracy z dziećmi. Mali aktorzy na scenie ekspresji nie byli marionetkami w rękach reżysera, byli autentycznymi współtwórcami scenariusza, scenografii i granych przez siebie postaci. Dorman pozostawiał swoim aktorom swobodę, która nie tylko potwierdzała zaufanie mistrza do wychowanków, lecz także przynosiła zaskakujące efekty artystyczne. Reżyser z powagą traktował swojego widza i poważnie traktował swojego aktora, dlatego przemawiał do podopiecznych ich językiem, językiem zabawy. Nie ma w tym sprzeczności ani konfliktu, szacunek do dzieci wymaga bowiem próby ich zrozumienia, współdziałania z nimi na dostępnej im płaszczyźnie. Wrodzoną aktywnością dziecka jest zabawa, dziecko funkcjonuje i rozwija się prawidłowo wtedy, kiedy może w sposób nieskrępowany wyrażać swój świat poprzez swobodne działanie przynoszące mu przyjemność. Iwona Dowsilas przez lata przypatrywała się pracy ojca, jej spostrzeżenia to kompleksowe spojrzenie na koncepcje Dormana:

${ }^{13}$ S. Poll a k, Błok w dziwnym teatrze, „Dialog” 1971, nr 2, s. 125.

${ }^{14}$ T. O grodzińs ka, Dormana teatr..., s. 155. 
Jego spektakle nie miały wątków fabularnych. Był to teatr improwizowany, podbudowany rytmicznością tekstu i dobrą muzyką. W swoim założeniu miał przemawiać do wrażliwości i wyobraźni dziecięcej, miał wywoływać skojarzenia. Dziecięcy instynkt zabawy przekształcał w instynkt teatralny ${ }^{15}$.

Odczucia córki, której z uwagi na pokrewieństwo zawsze można zarzucić mitologizowanie postaci ojca, potwierdzają słowa innych ludzi powiązanych z teatrem. Teresa Ogrodzińska, krytyk zajmujący się teatrem lalkowym, na łamach miesięcznika „Dialog” szczegółowo opisywała Dormanowską koncepcję „zabawy w teatr". Jej zdaniem:

Obserwacje zabaw dzieci - tych zbiorowych i tych samotnych, z lalką czy misiem, które uruchamiają wyobraźnię - zwróciły uwagę Dormana na rolę zabawy w życiu i spontanicznej twórczości dziecka. Myśląc kategoriami wychowawcy przenosił zabawę do teatru, uważając, że jest to konwencja dziecku najbliższa, więc taka, która pozwoli na nawiązanie szybkiego, ścisłego porozumienia z widzami. Myśląc kategoriami artysty preparował zabawę na potrzeby swojego teatru, wydobywał z niej czystą formę, a więc przede wszystkim rytm, rytualną powtarzalność zachowańn ${ }^{16}$.

Sam Dorman wielokrotnie podkreślał, że inspiracją dla jego koncepcji były spostrzeżenia wyniesione z obserwacji dziecięcych zabaw, były to dla niego na tyle wartościowe doświadczenia, że na ich podstawie opracował program „zabawy w teatr". Oddając głos samemu zainteresowanemu, który w miesięczniku „Scena” podzielił się z czytelnikami swoimi przemyśleniami, należy zwrócić uwagę na sposób, w jaki opisuje Dorman urok dziecięcych działań i żywiołowy efekt, jaki one przynoszą:

Spontaniczność leżąca w naturze aktu twórczego dziecka sprawia, że dzieło sceniczne mimo swojej nieporadności i naiwności zawsze jest świeże, oryginalne, a przede wszystkim niepowtarzalne. Słowo, ruch, przestrzeń ujęte $w$ formę zabawy, podporządkowane schematowi tej zabawy, przez magię nowych zestawień objawia nam zjawisko „świeżego znaczenia”"17.

Teatr Dormana nie bez powodu nazywano „laboratorium doświadczeń scenicznych", nowatorstwo zastosowanych w nim środków wyrazu zaskakuje do dnia dzisiejszego. Autor rezygnuje z teatru ilustrującego rzeczywistość, zastępując go teatrem skojarzeń, zmuszającym do myślenia i konfrontacji z własną wyobraźnią. Niezwykle trafnie działania artystyczne Dormana podsumowała Irena Sławińska w artykule Poszukiwanie nowego modelu. Teatr w środowisku robotniczym, pisząc:

Trudny jest teatr Dormana i wymyka się wszelkim kwalifikacjom. Odchodząc od teatru tradycyjnego, który nazywa ilustracyjnym, Dorman odwołuje się w swoich inscenizacjach przede wszystkim do folkloru podwórkowych zabaw dziecięcych. Rezygnuje w nich z uproszczonej funkcji wychowawczej, stawiając na emocje młodego widza, na zdolność kojarzenia. Literatura jest dla niego zaledwie punktem wyjścia, na kanwie której rozwija swoje pomysły inscenizacyjne. Po jego spektaklach pozostaje w pamięci typ teatru, nie zaś treść, tematyka zostaje ledwie zaznaczona. Dorman nie obawia się jednak eksperymentu nawet wobec surowego widza i ma rację, kiedy zapewnia, że jest to najlepsza droga do edukacji teatralnej ${ }^{18}$.

${ }^{15}$ I. Dowsilas, Niezwykły teatr..., s. 4.

${ }^{16}$ T. Ogrodziń s ka, Dormana teatr..., s. 153.

17 J. D o r m a n, Otwarcie teatru, „Scena” 1972, nr 12, s. 18.

${ }_{18}$ I. Sławińska, Poszukiwanie nowego modelu. Teatr w środowisku robotniczym, „Trybuna Robotnicza" 1975, nr 39, s. 6. 
Opisując koncepcję Dormana „zabawy dzieci w teatr” nie można nie wspomnieć o zasadzie spontanicznej aktywności dziecięcej, która wpisywała się w zakładany przezeń wzorzec działań inscenizacyjnych. W przywołanym wcześniej miesięczniku „Scena” Dorman w roku 1978 zamieścił obszerny artykuł pt. Hanka czyli zabawa dzieci w teatr, w którym wyjaśnił zasady swojej pracy i jej cele:

Działalność mojego teatru w latach 1945-1947, tak zwana zabawa dzieci w teatr, to przeciwwaga tego wszystkiego, co obciążało niefortunne poczynania szkoły czy domu. Zabawa w teatr polegała na spontanicznym przedstawianiu aktualnych wydarzeń wziętych z życia dzieci; na odgrywaniu improwizowanych scen opartych na zabawach podwórkowych; na odgrywaniu scen zaczerpniętych $z$ literatury dziecięcej. A forma tego teatru? To konwencja commedii dell'arte. A strona organizacyjna, wychowawcza? W teatrze zabawy występowały dzieci, te wszystkie, które z własnej woli zgłosiły chęć udziału w zajęciach teatru. Ta dobrowolna rekrutacja „aktorów” do zabawy w teatr pozwalała zgromadzić w świetlicy teatru dzieci w różnym wieku, z różnych środowisk, o różnych zainteresowaniach ${ }^{19}$.

To właśnie taką postawą Dorman zyskał uznanie profesora Stefana Szumana, który w adresowanym do Ministerstwa Oświaty zaświadczeniu popierającym działalność reżysera pisał:

Realizacja teatru zabawy przez dzieci w tej formie, jaką miałem sposobność oglądać, również mnie przekonuje, jako że chodzi w tym nie o efekt dla widza, lecz o przeżycia i osiągnięcia dzie$\mathrm{ci}$, dające im swoisty, a ważny teren rozwojowych możliwości. Teatr w tej formie może skutecznie przeciwdziałać jednostronnej racjonalizacji szkolnego systemu wychowawczego i społecznie dobrze wychowywać 20 .

Jako pedagog, Dorman widział w edukacji teatralnej niezastąpione możliwości wychowawcze, dziś powiedzielibyśmy, że kładł szczególny nacisk na rozwój inteligencji emocjonalnej u swoich podopiecznych. Zabawa w teatr miała być drogą do poznania samego siebie i otaczającego świata, uczyła współdziałania, pobudzała wyobraźnię, budowała system wartości. Dorman opublikował w dwutygodniku „Górnik”, w rubryce „Teatr w świetlicy” cykl artykułów opisujących jego założenia twórcze i wychowawcze. W publikacji Teatr zawodowy a teatr ochotniczy podkreślał, jak istotna wychowawczo jest praca zespołowa:

Jednostka przez pracę teatralną wypowiada się artystycznie, a jednocześnie wyczuwa wspólny rytm zespołu. Ścieranie się indywidualności i upodobań łagodzi wspólnie poniesiony wysiłek i wspólne przeżycie ${ }^{21}$.

Dzieci, biorące udział w działaniach grupowych, podlegają szybszej socjalizacji i uczą się właściwych wzorców zachowań, co przekłada się na ich rozwój emocjonalny. Takie działania wychowawcze w kontekście historycznym miały głęboki sens i nieocenione znaczenie, Dorman wielokrotnie podkreślał, że dzieci naznaczone piętnem wojny wymagają szczególnego podejścia - chciał przy-

19 J. D o r m a n, Hanka czyli zabawa dzieci w teatr, „Scena” 1978, nr 12, s. 31.

20 S. S z u m a n, Zaświadczenie adresowane do Ministerstwa Oświaty, rękopis, Archiwum Jana Dormana w Będzinie.

${ }^{21}$ J. D o r m a n, Teatr zawodowy a teatr ochotniczy, "Górnik” 1947, nr 3, s. 11. 
wrócić im radość dzieciństwa i wymazać z ich pamięci traumatyczne przeżycia. Efekt twórczy w postaci wystawienia spektaklu miał dla niego mniejsze znaczenie niż sama praca wychowawcza, kształcenie wrażliwości i postaw moralnych podopiecznych. Z takiego podejścia do wartości edukacji teatralnej w procesie kształtowania zdolności adaptacyjnych dziecka wynika, że Dorman miał świadomość, jak istotną rolę w rozwoju społecznym człowieka odgrywa pozyskanie kluczowych zdolności emocjonalnych. Okres dzieciństwa to moment tworzenia się szkieletu umiejętności interpersonalnych, budowania poczucia własnej wartości, formowania osobowości. Dorman wiedział, że systematyczny udział dziecka w zajęciach teatralnych jest przepustką do harmonijnego rozwoju intelektualnego i emocjonalnego. Dzięki uczestnictwu w „zabawie w teatr” dziecko miało szansę wyzbyć się własnych zahamowań, zdobyć pewność siebie i poczucie własnej wartości. Sam Dorman ujmował tę kwestię słowami:

Gra dziecka powinna być naturalna. Gra naturalna odbiera dzieciom nieśmiałość, wyswabadza psychikę dziecka, uczy swobodnego wyrażania się, swobodnego śmiania, unikania form sztywności22.

To właśnie radość z tworzenia, z zabawy, z możliwości oczyszczenia się z przytłaczających doświadczeń była dla Dormana kluczowym elementem działań artystycznych. Jak twierdził:

Cała istota przygotowanego widowiska, jego oryginalność, leży nie w tym, że dzieci świetnie grają, lecz w tym, że w zabawie, tej zabawie w teatr, znajdują możliwość wyrzucenia z siebie nagromadzonych przeżyć. Głównym celem pracy teatru z dziećmi jest droga do spektaklu, są to próby i zajęcia z dziećmi. Nie liczy się zatem wynik i świetność realizacji przedstawienia ${ }^{23}$.

Z takiego podejścia do „gry aktorskiej” wynika kolejne założenie Dormanowskiej koncepcji teatru, łączące się z zabawą i nieskrępowanym wyrażaniem siebie - improwizacja, w której artysta widział siłę działania i „świeżość” przedstawienia. Doskonałym przykładem jest opowieść Dormana o otwarciu Eksperymentalnego Teatru Dzieci w roku 1946, kiedy to w dniu premiery reżysera dopadła trema i obawy, czy jego praca zyska uznanie. Na kilka minut przed galą do Dormana podeszła mała dziewczynka, która poprosiła go o możliwość zagrania w przedstawieniu. Choć nie brała udziału w próbach, nie znała przedstawienia, chciała dostać rolę. Wszystkie dylematy reżysera przestały mieć znaczenie, w tamtej chwili Dorman miał już tylko jeden cel: znaleźć rolę dla niefrasobliwego dziecka. Dorman opisuje swoje odczucia słowami:

Dziewczynka wierzyła. Wierzyła, że nie odrzucę propozycji. Jakby wiedziała, że jedną z zasadniczych cech mojej postawy jest łapczywość chwytania uroku chwili; metoda impulsywnego korzystania z przypadków. Dobrze. Zgadzam się. Jednak jaką dać rolę dziewczynce, która przychodzi na minutę przed otwarciem teatru i chce grać. I oto wszystko, co do tej chwili mnie interesowało: spektakl, premiera, uznanie - stało się nieistotne. Ważna stała się propozycja dziewczynki. Punkt ważności przesunął się w stronę, jak pomóc małej, która chce grać? Nie było czasu na uporządkowanie sytuacji. Jedyna rzecz to improwizacja ${ }^{24}$.

22 J. D or m a n, Zabawa dziecka jest grą, tamże, nr 5, s. 11.

${ }^{23}$ J. Dorman, Otwarcie..., s. 18.

24 Tamże. 
Jeśli wierzyć słowom artysty, mimo presji jaką odczuwał z powodu rangi wydarzenia, natychmiast zdecydował się zaspokoić potrzebę twórczą dziecka, bez względu na konsekwencje dla całego przedstawienia i uroczystości. Pod wpływem, jak sam to określił, „olśnienia” znalazł dla dziewczynki rolę - miała odczepić ozdobną wstążkę, przejść z nią wzdłuż sceny, co stanowiło symboliczną inicjację działalności teatru.

Wspominał:

Teraz cała ceremonia otwarcia teatru zależna jest od tego, jak się zachowa dziewczynka, jak odegra rolę, której wcześniej nie próbowała. Wydarzenie, jakie za moment stanie się zdarzeniem lub fiaskiem zależne jest od niej i od mojej zgody. Biorę na siebie świadomie odpowiedzialność za wynik tego wydarzenia ${ }^{25}$.

Według Dormana, dziewczynka w swojej roli poszła dużo dalej niż zakładał to ad hoc skonstruowany plan reżysera, bez niczyjej sugestii i podpowiedzi wypowiedziała kilkakrotnie słowa: „Otwieram teatr”. Ta samowolna improwizacja spotkała się z niezwykłym aplauzem publiczności, Dorman zaś stwierdził:

Gdybyśmy uzgodnili tekst, gdybyśmy w najdrobniejszych szczegółach ustalili sytuację, to nie potrafilibyśmy wyczuć magicznej funkcji tych słów; brakowałoby żarliwości, prostoty, dziecięcego wdzięku, poezji, owego „wyładowania elektrycznego”, jakie nastąpiło właśnie podczas występu w interpretacji dziewczynki ${ }^{26}$.

Improwizacja była więc w teatrze Dormana zasadą, której artysta nie potrafił się oprzeć, dzięki czemu przedstawienia wystawiane przez niego miały w sobie elementy zaskoczenia i niosły powiew nowości. To „zwycięstwo” improwizacji i przypadku nad banalnymi zwyczajami obowiązującymi od lat (których atrybutami są nożyczki, wstęga i przemówienie), ucieczka od sztampy stopniowo rodziły u Dormana przeświadczenie o konieczności podporządkowywania wszelkich konwencji, kanonów, sposobów konkretnym, własnym celom artystycznym, „do robienia tego, co zasługuje na robienie”, „co nigdy jeszcze nie było robione”, „co daje swobodę twórczą"27. Maksyma, której był wierny - „improwizacja i przypadek!" - potwierdziła się w praktyce teatru ${ }^{28}$.

Na deskach Teatru Dzieci Zagłębia, gdzie grali „dorośli” aktorzy, improwizacja również wpisana była w scenariusz rodzącego się przedstawienia, to na próbach powstawały kolejne pomysły na uatrakcyjnienie widowiska. Poszczególne „partytury” scenariusza poddawane były wielokrotnej transformacji, szukano tego, co najbardziej przyciągnie uwagę widza. Wspomniana już Maria Mikołajczyk po przyjrzeniu się pracy zespołu aktorskiego napisała:

Podczas próby obejrzeliśmy wiele wariantów, improwizacji tej samej sceny, różne ustawienia ruchu aktorów, zgrywanie płynnego przejścia od jednego elementu do drugiego. Reżyser kierujący

\footnotetext{
25 Tamże, s. 18-19.

26 Tamże, s. 19.

27 Tamże.

28 Tamże.
} 
zespołem potrafił rzeczywiście wciągnąć aktorów do wspólnej zabawy; improwizowana orkiestra wymyśliła np. dodatkowy instrument - grzebień! A jednocześnie zadziwiał poważny stosunek wszystkich współtworzących do rodzącego się dzieła! ${ }^{29}$.

Umieszczenie Teatru Dzieci Zagłębia w koncepcyjnych ramach teatru lalki, wbrew początkowym obiekcjom, okazało się szczęśliwym rozwiązaniem. Dorman, wielki przeciwnik dosłowności w teatrze, znalazł sposób na epatowanie swojego widza skojarzeniami, umowną rzeczywistością, symboliką sceniczną. Przełomowym spektaklem był Krawiec Niteczka - wtedy to Dorman wstrząsnął światem teatru lalkowego, odrzucając nieodzowny dotąd jego atrybut - parawan. Wyprowadzając aktora zza parawanu stworzył nową jakość w teatrze lalki, aktor przestał być bowiem anonimowy, stał się „opiekunem” lalki, jej partnerem, poruszał się niezależnie od niej. Dzięki temu zabiegowi Dorman rozbił sceniczne poczucie rzeczywistości, uzyskując efekt umowności i wieloznaczności, który, według niego, stanowił przyczynek do stałej aktywności i skupiania uwagi, jednocześnie odwołując się do wyobraźni i skojarzeń. Wówczas to, zdaniem Teresy Ogrodzińskiej:

Po raz pierwszy dziecięca zabawa urosła do rangi zasady inscenizacyjnej. Dorman wyprowadził aktorów z lalkami przed parawan, podkreślając umowność konwencji teatralnej. Zastosował różnorodne środki wyrazu - obok lalki pojawiła się maska i emblemat, zaś lalka została sprowadzona do funkcji znaku. W tradycyjnym teatrze lalka tworzyła samodzielną postać teatralną, którą budował skryty za parawanem aktor. U Dormana na postać sceniczną składał się aktor z lalką, która sygnalizowała jedynie pewne cechy bohatera. Oto Krawiec Niteczka: wyrazista głowa lalki osadzona na długiej szyi, niżej ramiączko do wieszania ubrań; ręce aktorki animującej lalkę były jednocześnie dłońmi Krawca ${ }^{30}$.

Nowatorstwo posunięcia Dormana odbiło się szerokim echem w środowisku teatralnym, zachowawcza „opozycja” twierdziła, że reżyser wprowadza chaos i zamieszanie do spektaklu. Bardziej postępowi recenzenci dostrzegali w decyzji artysty rewolucyjny sposób na demaskowanie rzeczywistości scenicznej, a w konsekwencji na nowe estetyczne doświadczenie teatralne, tak różne od tego, co zwykle spotkać można było w twórczości adresowanej do dzieci. Bogdan Możdżyński, po obejrzeniu przedstawienia, pisał:

Spektaklem „Krawiec Niteczka” Dorman przekroczył teatralny Rubikon - zaproponował teatr lalek, jakiego dotąd $w$ Polsce nie znano. Zaproponował teatr... raczej przesunął lalki w obręb teatru umownego, niektórzy mówili o eksperymentach, inni wręcz o rewolucji. Co zrobił Dorman? Ano przede wszystkim usunął parawan. W ten sposób widz ujrzał i aktora, i lalkę (lub maskę) równolegle dopełniających określoną postać. Takie podwójne oznaczenie postaci podkreślało i odsłaniało nie tylko jej umowność, ale i umowność całego spektaklu, całego teatru. Zdjęcie parawanu miało poważne konsekwencje artystyczne. Widz - z reguły dziecko - otrzymywało rzeczywistość podwójną, rozbitą ${ }^{31}$.

Dorman, poszukując nowych sposobów odwoływania się do dziecięcej wyobraźni i skojarzeń, użył sprawdzonej już metody - zabawy. Sama konstrukcja przedstawienia to powtarzające się rytmicznie kwestie, jak dziecięce rymowanki,

${ }^{29}$ M. Mikołajczy k, Dzieci nauczyły mnie..., s. 5.

30 T. O grodziń s k a, Dormana teatr..., s. 151.

31 B. M ożd ż y ń s k i, I znowu gram krowę, „Sztandar Młodych” 1976, nr 240, s. 4. 
wpływające na melodyjność przedstawienia. Reżyser zawsze dbał o właściwą oprawę muzyczną i plastyczną swoich widowisk, jednak tym razem doświadczenia wyniesione z eksperymentalnego „laboratorium” z Sosnowca zatriumfowały z całą mocą na scenie teatru zawodowego:

Cała inscenizacja odwołuje się do wyobraźni widza: akcja na scenie jest jakby katalizatorem współrzędnej akcji, podjętej i rozgrywanej przez wyobraźnię dziecka. Jeśli podbija do tego stopnia widownię, to dlatego, że apeluje do instynktu zabawy. Pierwiastek zabawy dominuje w inscenizacji i w dramaturgii „Krawca”, określając konwencję gry i budowania sytuacji scenicznych. Nawet niektóre z kwestii powtarzane są rytmicznie, rozłożone na głosy, lub miarowo wystukiwane, podobnie jak czynią to dzieci odliczające przed rozmaitymi grami i zabawami2.

Kolejne przedstawienia Teatru Dzieci Zagłębia były stopniowo poszerzaną kontynuacją praktyki wyniesionej z „zabawy dzieci w teatr” - przedstawienia nie miały typowej akcji, aktorzy grali różne postaci, zmieniając jedynie maski, lalki i rekwizyty, które były znakiem plastycznym podkreślającym umowność sytuacji. Dorman był wielkim przeciwnikiem teatru iluzyjnego, odtwórczego, dosłownego, w jego odczuciu taki teatr pozbawiał dzieci możliwości fantazjowania, prawdziwego przeżywania, kojarzenia i asocjacji zjawisk. Widowiska Dormana były pełne metafor, poetyckie, często wymagały odległych nawet skojarzeń, zmuszały dzieci do aktywności i uwagi. W obszernym artykule pt. Moje credo artystyczne Jan Dorman pisał:

Szukam tych wszystkich dróg, gdzie niepotrzebna jest iluzja, która każe wierzyć widowni w udawaną grę aktorów i w dekoracje. Chcę, aby widz potrafił odczytać wszystkie znaki, których używam przy budowie moich inscenizacji. Najczęściej żądamy, aby dzieło sztuki zawierało jakieś moralne wartości, pokazywało ludzi w ich walce o wartość idei. Moje żądania są skromniejsze: chciałbym, aby widz potrafił odnaleźć w teatrze wartości estetyczne, które prowadzą do zrozumienia integralności wszystkich zjawisk rodzących piękno ${ }^{33}$.

Istotną częścią jego koncepcji stały się rekwizyty - proste przedmioty przeniesione z codziennego życia na deski teatru ożywały, zaczynały pełnić ważną rolę w działaniach scenicznych. Na poszczególnych rekwizytach koncentrowała się uwaga widzów, były one osią konstrukcyjną danego fragmentu sztuki. Rekwizyt potrafił stać się bohaterem, tak samo istotnym jak postać kreowana przez aktora. Zdarzało się, że ten sam rekwizyt w jednym przedstawieniu pełnił szereg różnych funkcji, co dobitnie podkreślało umowność rzeczywistości teatralnej. Andrzej Linert w artykule Teatry lalkowe w dawnym województwie katowickim (1945-1975) podkreśla:

Dużą rolę w budowaniu konstrukcji dramatycznej danego spektaklu odgrywa rekwizyt. Najczęściej jest to przedmiot wzięty z najbliższego otoczenia, na przykład wieszak, maska obrzędowa, zużyta opona, puste pudełko blaszane. Jednakże z chwilą, gdy zostaje przeniesiony na scenę, wokół niego zaczynają się organizować: życie sceny, jej logika i przestrzeń. W dalszym ciągu przedstawienia rekwizyt decyduje o układzie partytury i od niego zależne są zarówno motywacje, jak i porządek

\footnotetext{
32 J. P u ge t, Gdzie kozy kują, tam drwa lecą, „Współczesność” 1959, nr 3, s. 3.

33 J. D orm a n, Moje credo artystyczne, „Polska” 1969, nr 6, s. 61.
} 
poszczególnych fraz konstrukcji scenicznych. Od niego zależą też: ruch, światło i muzyka. W pracy scenicznej Dormana rekwizyt pełni więc funkcję inspirującą, jest impulsem do dalszego działania, reguluje przebieg akcji34.

Aktorzy Teatru Dzieci Zagłębia, podobnie jak rekwizyty, nie mieli przypisanych na stałe ról, ubrani w pasiaste uniformy (Przygody Wiercipięty, rok 1961) bądź w kombinezony z napisem „Teatr Dzieci Zagłębia” (Która godzina, rok 1964) przejmowali różne funkcje, zmieniając jedynie maski lub inne drobne elementy stroju. Dormanowi jednak nawet ten zabieg nie wystarczał, w swojej koncepcji poszedł jeszcze krok dalej - niektórzy aktorzy występowali w tych samych kostiumach i rolach, ale w różnych przedstawieniach. O innowacyjności poczynań reżysera Lucyna Kozień pisała:

Teatr Dormana nazywany był teatrem konwencji, teatrem zabawy dziecięcej, teatrem skojarzeń i teatrem kolażu; sam artysta często podkreślał, że jego teatr wywodzi się z podwórka, a system i metoda pracy twórczej tkwi w wyliczankach, które narzucają spektaklom określony rytm i dramaturgię. „W zasadzie wciąż robię ten sam spektakl” - twierdził Jan Dorman i rzeczywiście do kolejnych przedstawień wprowadzał te same motywy i opowiadał wciąż tę samą historię. Aktorzy Dormana grywali te same role $w$ wielu kolejnych przedstawieniach, zakładali te same kostiumy i nierzadko wypowiadali kwestie znane z innych sztuk. Działali jako zespół, a ich zadania wynikały z rytmu spektaklu ${ }^{35}$.

Na deskach Teatru Dzieci Zagłębia nie było miejsca na "gwiazdorstwo”, nie było miejsca na indywidualizm aktora, aktor tak samo jak tekst scenariusza, oprawa plastyczna czy muzyka służył spektaklowi. Sam zespół aktorski teatru był nieliczny, a specyfika placówki wymagała od aktorów licznych zdolności, oprócz oczywistej w teatrze lalkowym umiejętności animacji lalki, także biegłości w charakterystycznej u Dormana grze scenicznej. Dorman w swoich spektaklach kładł szczególny nacisk na gest i ruch jako środek artystycznego wyrazu, zaznaczyć należy jednak, że gesty i ruchy całego zespołu aktorskiego były powtarzane, umowne i podporządkowane muzycznemu rytmowi. Te same ruchy były często kopiowane jako motywy w różnych przedstawieniach. Aktorzy musieli pozbyć się osobistych ambicji, bo na scenie u Dormana nie było miejsca na „kult jednostki”, nawet w programach przedstawień nie podawano szczegółowej obsady z podziałem na wykonywane role. Programy spektakli zawierały jedynie nazwiska uczestników przedstawienia, nie informowały jednak, w jaką dana osoba wciela się postać. Trzeba w tym miejscu podkreślić, że bohaterowie inscenizacji Dormana byli jakby dwojako konstruowani; część zespołu obsadzana była w niezindywidualizowanych rolach, tak, by mogli szybko przeobrażać się w kolejnych bohaterów, zgodnie z potrzebami spektaklu, było też kilkoro aktorów na stałe obsadzonych w danej roli. Henryk Jurkowski twierdzi:

W Teatrze Dzieci Zagłębia uprawia się aktorstwo szczególnego rodzaju. Aktorzy działają przede wszystkim jako zespół. Szukają wyrazu dla postaci scenicznych w dziecięcych rytmach i melodycznej

${ }^{34}$ A. L in e rt, Teatry lalkowe w dawnym województwie katowickim (1945-1975), „Zaranie Śląskie" 1975, z. 4, s. 511.

35 Zob. L. Ko zi eń, Jan Dorman..., s. 54. 
recytacji tekstu. I tylko niektórzy z nich mieli szansę wystąpienia w „prawdziwych” rolach, kiedy to mogli być danymi postaciami. Niektórzy z nich posiedli jedną tylko taką rolę i pozostali w niej na zawsze, przenosząc ją i do innych sztuk, jeśli w nich występowali36.

Pisząc o Janie Dormanie w kontekście jego dokonań artystycznych związanych z dziećmi, nie sposób nie wspomnieć o teatrze dla przedszkolaków. W Teatrze Dzieci Zagłębia powołano do życia specjalny zespół aktorski przygotowujący widowiska dla najmłodszej widowni, która nie jest jeszcze obeznana ze sztuką i teatrem. Już w latach 50. wprowadził Dorman do repertuaru krótkie, dwudziestominutowe przedstawienia, grane bezpośrednio w przedszkolach. Oryginalność tego pomysłu polegała na tym, że po występie aktorzy, jakby przez roztargnienie, pozostawiali w goszczącej ich placówce jakiś rekwizyt teatralny, najczęściej była to lalka. Dzięki temu zabiegowi spektakl „trwał” dalej. Artyści opuścili przedszkole, natomiast dzieci fantazjowały na temat dalszych losów lalki, rysowały ją, malowały dla niej. Zebrane doświadczenia posłużyły niezwykłemu eksperymentowi, jaki Dorman przeprowadził w toku inscenizacji spektaklu Kaczka. Pierwsza jego część odbyła się w przedszkolu, do którego aktorzy przywieźli rekwizyt teatralny - kaczkę. Dzieci zaprzyjaźniły się z nią i wprowadziły do swoich zabaw, by jakiś czas później zobaczyć ją w całkiem innej sytuacji - na scenie w teatrze. W ten sposób konstrukcja świata scenicznego zarysowała się początkowo w zabawach dzieci w przedszkolu i kiedy obejrzały ją przetworzoną w sposób artystyczny na scenie, była im bliska i nie budziła żadnych obaw. Dorman trafnie podkreślał znaczenie przygotowania dziecka do percepcji przedstawienia teatralnego. Odnajdywanie w świecie scenicznym obrazu własnych zabaw i znajomych rekwizytów zbliża ten świat do subiektywnego świata dziecka i wzmacnia oddziaływanie fikcji teatralnej.

Kontynuując swoją koncepcję eksperymentalnego teatru dla przedszkolaków, w roku 1975 artysta na scenie będzińskiego teatru wystawił spektakl pt. Konik. Przedstawieniem tym udowodnił, że dziecku wystarczy podsunąć tematy, dawać znaki, elementy do budowy fabuły, a reszta rodzi się w jego wyobraźni i uzależniona jest od indywidualnej wrażliwości małego odbiorcy.

Dormanowska koncepcja teatru dzieci i dla dzieci była dobrze przemyślana i spójna, jej fundament stanowił młody człowiek i wszystko to, co było jego światem. Artysta wspierał swoimi działaniami scenicznymi rozwój dziecięcej aktywności twórczej, często powtarzał, że teatr ma zmuszać do myślenia, a nie definiować myśli. Teatr Dormana nazywany był teatrem metafory, teatrem kolażu, teatrem skojarzeń. Dorman usiłował zaszczepić w dzieciach miłość do teatru, do sztuki, do piękna. Zdaniem Olgierda Błażewicza:

Przede wszystkim jednak Dorman chce wprowadzić swoich odbiorców w świat sztuki. Nauczyć ich różnych konwencji, poetyk teatralnych i sposobów interpretowania rozgrywających się na scenie zdarzeń. Chce wyzwolić w nich naturalne, nie zawsze przecież uświadamiane, predyspozycje twórcze. Uczynić ze swoich widzów jednostki aktywne, zdolne zrozumieć i odczuć najistotniejszy sens sztuki ${ }^{37}$.

${ }^{36}$ H. J u rk o w s k i, Teatr Dzieci Zagłębia 1945-1974, „Pamiętnik Teatralny” 1976, nr 3, s. 8.

${ }^{37}$ O. Bła ż ew i c z, Teatr Jana Dormana, „Tydzień” 1976, nr 42, s. 4. 
Z pozoru teatr w Będzinie mógł jawić się jako gmatwanina motywów, rekwizytów i niezindywidualizowanych postaci, chaotycznie wałęsających się po scenie, jednak sam artysta widział w swoich działaniach bramę do dziecięcej wyobraźni, której uruchomienie przyniesie chęć aktywnej działalności twórczej dziecka. Jednego z pewnością nie można odmówić Dormanowi - pasji tworzenia, kształtowania młodych umysłów, uwrażliwiania ich na piękno. W prasie na przestrzeni sześćdziesięciu lat ukazało się wiele artykułów traktujących o twórczości artystycznej Dormana, był uwielbiany i krytykowany, budził podziw i kontrowersje, z pewnością jednak nikt, kto zetknął się z jego teatrem, nie przeszedł obok niego obojętnie. Najpełniejszym podsumowaniem aktywności Dormana są słowa Joanny Gorczyckiej:

Kto widział przedstawienia Teatru Dzieci Zagłębia z Będzina, ten wie, jaki rodzaj fascynacji może go spotkać. Kto nie widział $-\mathrm{z}$ relacji niewiele zrozumie... Cały Dorman ${ }^{38}$.

38 J. Gor c z y ck a, Inicjacja przyszłego widza, „Teatr” 1978, nr 18, s. 13. 